Bangladesh Journal of Anatomy July 2011, Vol. 9 No. 2 pp 79-83

\title{
Morphometric Study of The Human Pituitary Gland
}

\author{
Mushfika Rahman ${ }^{1}$, Shamim Ara², Halima Afroz ${ }^{3}$, Nurun Nahar ${ }^{4}$, \\ Anjuman Ara Sultana ${ }^{5}$, Kaniz Fatema ${ }^{6}$
}

\begin{abstract}
:
Context: The pituitary gland produces several hormones which regulate growth, metabolism and reproduction. Deviations from the normal morphometry and functions of the gland certainly derange the harmony of life.
\end{abstract}

Objective: The study was carried out to identify morphological variation of pituitary gland in relation to age.

Materials \& Methods: A cross-sectional, descriptive type of study was carried out in the Department of Anatomy, Dhaka Medical College, Dhaka, from July 2009 to June 2010 on 60 post mortem human pituitary glands (40 male and 20 female). The samples were divided into four groups and length, width \& height of the pituitary gland were recorded in $\mathrm{mm}$ by using a digital slide calipers.

Results: The length was noted as $6.35 \pm 0.48,5.93 \pm 1.08,5.35 \pm 0.48$ and $5.11 \pm 0.27 \mathrm{~mm}$ in group $A, B, C$ and $D$ respectively. The width of the pituitary gland was $11.37 \pm 0.96,10.43 \pm 0.74,10.12 \pm 1.32$ and $9.07 \pm 0.38 \mathrm{~mm}$ in group $A, B, C$ and $D$ respectively. The height of the pituitary gland was found $6.35 \pm 0.48,5.69 \pm 0.86$, $5.34 \pm 0.92$ and $4.62 \pm 0.38 \mathrm{~mm}$ in group $A, B, C$ and $D$ respectively.

Conclusion: The length, width \& height of the pituitary gland showed gradual decreasing values with advancing age.

Key Words: Morphometry, Pituitary Gland.

\section{Introduction}

The pituitary gland (hypophysis cerebri) is a reddish grey, ovoid body lies within the hypophyseal fossa of the sphenoid bone, covered superiorly by diaphragma sellae, which is pierced centrally by an aperture for the infundibulum ${ }^{1}$. It is attached to the hypothalamic region of the brain by a narrow stalk and has both neural and vascular connections with the brain ${ }^{2}$. Structurally the gland is divided into a larger anterior region (adenohypophysis) and a smaller posterior region (neurohypophysis). They differ in development, types, arrangement of cells, in their vascular and neural innervations. The gland measures about $12 \mathrm{~mm}$ in transverse and $8 \mathrm{~mm}$ in antero-posterior diameter and weighs about 500

1. Assistant Professor. Department of Anatomy, Dr. Sirajul Islam Medical College,

2. Professor \& Head of the Department of Anatomy, Dhaka Medical College,

3. Assistant Professor. Department of Anatomy, Green Life Medical College.

4. Assistant Profesor, Department of Anatomy, Dhaka Central International Medical College.

5. Lecturer, Department of Anatomy, Shaheed Suhrawardy Medical College.

6. Asistant Professor, Department of Anatomy, Johurul Islam Medical College.

Correspondence: Dr. Mushfika Rahman $\mathrm{mg}^{2}$. Dynamic changes occur in the size, shape and signal intensity of the pituitary gland during life ${ }^{3}$. These changes reflect the complex hormonal environment of the gland and are most pronounced at times of hormonal flux, such as menarche and pregnancy ${ }^{3}$. Previous observers have noted transient changes which occur in the shape or signal intensity of the pituitary gland at different stages of life, which also reflect concurrent changing of hormonal levels. A radiological study on pituitary gland revealed that, there was a gradual but definite increase in both width and antero-posterior diameter of the pituitary gland with age and a decrease in height with age ${ }^{3}$. Pituitary adenomas are indolent tumors, which accounts for $10-15 \%$ of all diagnosed intracranial neoplasms ${ }^{4}$.A prospective cross sectional study in the Northern part of Bangladesh reveals that, the prevalence of hyperprolactinemia accounts for about $43 \%$ and $21 \%$ of primary and secondary infertility respectively ${ }^{5}$. Prolactinomas are accounting for about $60 \%$ of primary pituitary tumors ${ }^{6}$. The second most common type is somatotrophic adenoma which is characterized by elevated level of Growth hormone- results in gigantism and acromegaly before and after closure of epiphysis respectively ${ }^{7}$. About $25 \%$ of patients have diabetes insipidus ${ }^{8}$. 
To study the pituitary growth and for diagnosing and treating diseases affecting pituitary gland, normal morphometrical knowledge regarding pituitary gland is essential.

\section{Materials \& Methods}

\section{Materials:}

The present study was performed on 60 post mortem human pituitary glands of different age groups, of which 40 were male and 20 were females. Among them, the lowest age was 22 years in both sexes and the highest was 55 years in male and 45 years in female.

The samples were collected from the whole brains of the unclaimed dead bodies that were under examination in the Department of Forensic Medicine of Dhaka Medical College, Dhaka. After accomplishing all legal formalities the samples were collected within $24-36$ hours of death. The samples were brought to the Department of Anatomy, Dhaka Medical College, Dhaka. Soon after collection, each sample was gently washed with tap water on a dissection tray. Blood and blood clots were removed as far as possible. Then the samples were fixed in $10 \%$ formol saline solution.

\section{Methods:}

\section{Place and duration of study:}

This study was carried out in the Department of Anatomy, Dhaka Medical College, Dhaka, Bangladesh, from July 2009 to June 2010.

\section{Grouping of the samples:}

The samples were divided into four age groups. The age groups were group A (20-29 years), group B (30- 39 years), group $C$ (40-49 years) and group $D$
(50-59 years). Detailed grouping and distribution of samples for morphological study were shown in Table-I (after Tsunoda A, Okuda O) ${ }^{9}$.

Table- I

Grouping of the samples

\begin{tabular}{lccc}
\hline Group & $\begin{array}{c}\text { Age limit } \\
\text { in years }\end{array}$ & \multicolumn{2}{c}{ Number of samples } \\
& $20-29$ & 09 & Female \\
\hline A & $30-39$ & 17 & 09 \\
B & $40-49$ & 09 & 08 \\
C & $50-59$ & 05 & 03 \\
D & & \\
\hline
\end{tabular}

Measurement of length:

Immediately after collection, the length of the pituitary gland was measured by using a digital slide calipers in $\mathrm{mm}$. The length of the gland was measured from antero-posterior distance of the gland $^{10}$. Three readings were taken and the average result was noted.

\section{Measurement of width:}

The width of the gland was measured from the distance between the highest points of the lateral edges $^{11}$. Three readings were taken and the average result was noted.

\section{Measurement of height:}

Height of the gland was measured from the centre of the concavity that usually forms the superior surface of the gland (where no concavity, the greatest supero - inferior dimension) ${ }^{11}$. Three readings were taken and the average result was noted.

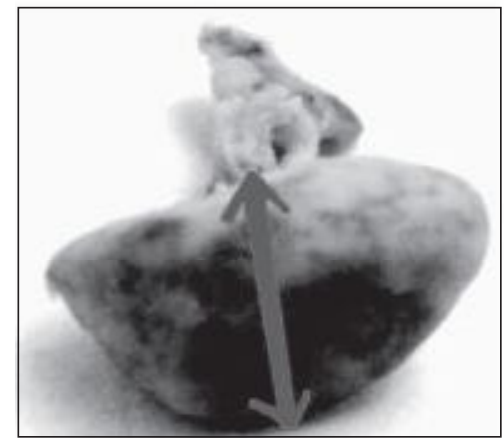

A

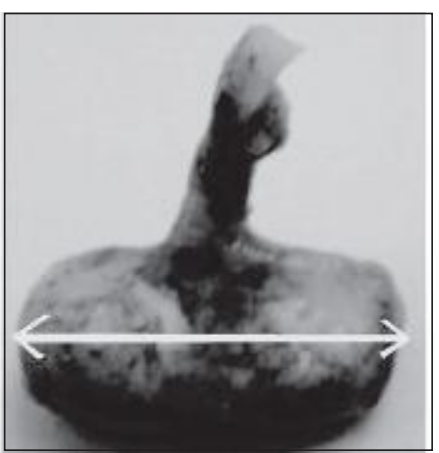

B

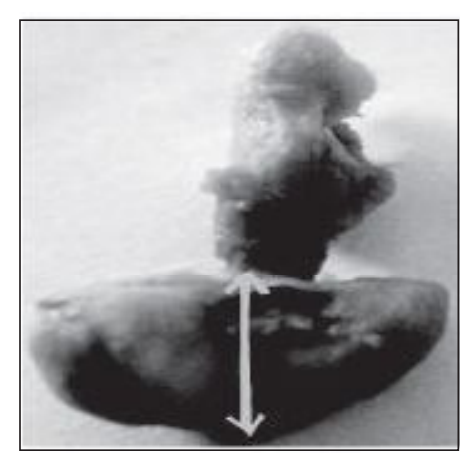

C

Fig-1: Showing the antero-posterior distance $(A=$ =length) from the inferior view and the transverse distance ( $B=$ width) and the supero-inferior distance $(C=h e i g h t)$ of the pituitary gland from the anterior view. 
Results

Results are shown in the Table-II, Figure- 2,3, \& 4.

Table - II

Results of the length, width and height of the pituitary gland

\begin{tabular}{lcccc}
$\begin{array}{l}\text { Group } \\
\text { (Age) in years }\end{array}$ & $\begin{array}{c}\text { Number } \\
(\mathrm{n})\end{array}$ & $\begin{array}{c}\text { Length }(\mathrm{mm}) \\
\text { Mean } \pm \text { SD }\end{array}$ & $\begin{array}{c}\text { Width }(\mathrm{mm}) \\
\text { Mean } \pm \text { SD }\end{array}$ & $\begin{array}{c}\text { Height }(\mathrm{mm}) \\
\text { Mean } \pm \text { SD }\end{array}$ \\
\hline A & 18 & $6.35 \pm 0.48$ & $11.37 \pm 0.96$ & $6.35 \pm 0.48$ \\
$20-29$ & & $(5.35-7.30)$ & $(9.97-12.79)$ & $(3.77-6.83)$ \\
B & 25 & $5.93 \pm 1.08$ & $10.43 \pm 0.74$ & $5.69 \pm 0.86$ \\
$30-39$ & & $(4.19-7.7)$ & $(8.32-12.53)$ & $(3.68-7.03)$ \\
C & 12 & $5.35 \pm 0.48$ & $10.12 \pm 1.32$ & $5.34 \pm 0.92$ \\
$40-49$ & & $(4.38-6.28)$ & $(8.31-12.87)$ & $(4.16-6.80)$ \\
D & 5 & $5.11 \pm 0.27$ & $9.07 \pm 0.38$ & $4.62 \pm 0.38$ \\
$50-59$ & & $(4.75-5.5)$ & $(8.50-9.50)$ & $(4.14-5.38)$ \\
\hline
\end{tabular}

$P<0.01^{* *}$; Length between group $A \& C, A$ \& .

$P>0.01$ ns; Length between group $A \& B, B \& C, B \& D, C \& D$.

$P<0.01^{\text {**}}$; Width between group $A \& B, A \& C, A \& D, B \& D$.

$P>0.01$ ns; Width between group $B \& C$ and $C \& D$.

$P>0.01$ ns; Height between group A \& B, A \& C, A \& D, B \& C, B \& D, C \& D.

$\mathrm{n}=$ Number of samples, $\mathrm{SD}=$ Standard deviation,

ns $=$ not significant ${ }^{* *}=$ significant .

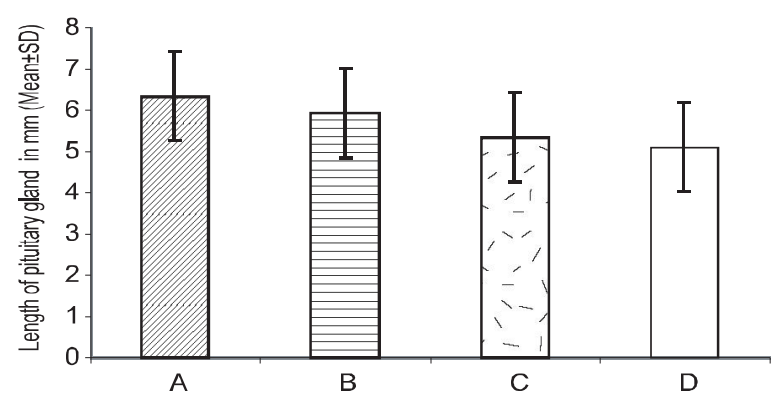

Fig- 2: Bar diagram showing the length of the pituitary gland in $\mathrm{mm}$ in different age groups.

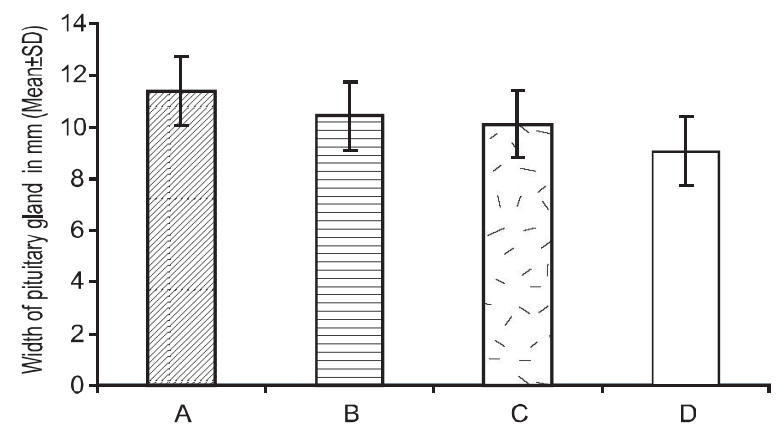

Fig.-3: Bar diagram showing the width of the pituitary gland in $\mathrm{mm}$ in different age groups.

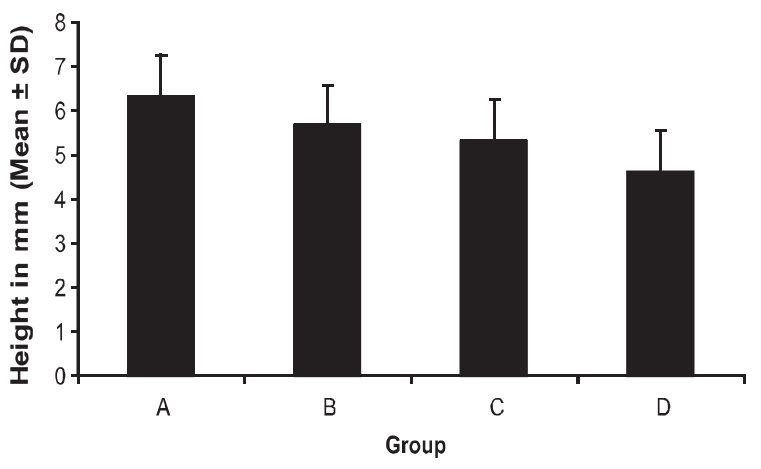

Fig.-4: Bar diagram showing the height of the pituitary gland in $\mathrm{mm}$ in different age groups.

\section{Discussion:}

In the present study the mean \pm SD of length of the pituitary gland was found to be $6.35 \pm 0.48,5.69 \pm$ $0.86,5.34 \pm 0.92$ and $4.62 \pm 0.38 \mathrm{~mm}$ in group $A$, $B, C$ and $D$ respectively, which was smaller to all the values that were found in texts or literatures. The gland is about $10 \mathrm{~mm}$ in length as stated by Fawcett ${ }^{12}$, Gartner and Hiatt ${ }^{13}$, Aron, Findling and Tyrrell ${ }^{6}$, Mescher ${ }^{14}$. Maitra ${ }^{8}$ found the length $9 \mathrm{~mm}$ which was much higher than the values of the 
present study. The reason of this difference may be due to racial variation of the study population. The study also revealed that mean \pm SD of length declines with age which was statistically significant and dissimilar to that Dietrich et al. in $1995^{3}$. Dietrich et $\mathrm{al}^{3}$ conducted an MRI study on 100 children ( $0-2$ years of age) and revealed increased antero-posterior diameter of the gland with age, e.g. the mean length was $6.79 \mathrm{~mm}$ and $8.16 \mathrm{~mm}$ in 0.1 1.5 weeks and 56-97 weeks aged children respectively ${ }^{3}$.

In the present study the mean \pm SD of width of the pituitary gland was $11.37 \pm 0.96 \mathrm{~mm}$ in group $\mathrm{A}$, which was close to the result of Oon, Lavender and Joplin ${ }^{15}$ conducted a radiological study on 33 adult autopsy subjects and revealed the range of width to be 11.5 to $16.1 \mathrm{~mm}$. Again in group $B, C$ and $D$, the mean \pm SD of width was $10.43 \pm 0.7,10.12 \pm 1.32$ and $9.07 \pm 0.38 \mathrm{~mm}$ respectively, which can be included within the range $(10-15 \mathrm{~mm})$ of width described by Kelly, Wood and Enders ${ }^{16}$, Fawcett ${ }^{12}$ , Gartner and Hiatt ${ }^{13}$. The study also revealed that mean \pm SD of width declines with age which was statistically significant $(P<0.01)$ and was dissimilar to the study findings of Dietrich et $\mathrm{al}^{3}$. Dietrich et al. ${ }^{3}$ in 1995 conducted an MRI study on 100 children (0-2 years of age) and revealed increased width of the gland with age, e.g. the mean width was 8.41 $\mathrm{mm}$ and $10.08 \mathrm{~mm}$ in 0.1-1.5 week and 56-97 week aged children respectively.

In the present study the range of height was 3.77 to 6.83 and 3.68 to $7.03 \mathrm{~mm}$ in group A and B respectively, which can be included within the range of height mentioned by Argyropoulou et al (3$7 \mathrm{~mm})^{17}$, Tien et al $(2-7 \mathrm{~mm})^{18}$, Aron, Findling and Tyrrell $^{6}$, Maitra ${ }^{8}(6 \mathrm{~mm})$. The mean \pm SD of height was $5.34 \pm 0.92 \mathrm{~mm}$ in group $\mathrm{C}$, which was near to that of Wolpert et al $^{19}$ (mean $5.7 \mathrm{~mm}$ ), Fawcett ${ }^{12}$, Gartner and Hiatt ${ }^{13}(5 \mathrm{~mm})$, Tsunoda, Okuda and Sato $(5.1 \pm 1.1 \mathrm{~mm})^{9}$. The mean $\pm S D$ of height was $4.62 \pm 0.38 \mathrm{~mm}$ in group $\mathrm{D}$, which was close to Elster et al. $(4.8 \mathrm{~mm})^{20}$. The present study recorded thatpituitary height peaked in the 20-29 age group and declined between 20-29 and 50-59 years (particularly in males) was similar to the study of Tsunoda, Okuda and Sato $^{9}$, but the differences were not statistically significant $(P>0.01)$. The present study also revealed that mean \pm SD of height declines with age which was statistically not significant but was similar to the study findings of Dietrich et $\mathrm{al}^{3}$.

\section{Conclusion:}

The observation and results of the present study are expected to standardize the morphology of the pituitary gland in Bangladeshi people. The length, width \& height of the pituitary gland showed gradual decreasing values with advancing age. Further studies to find out the cause of decreasing morphological parameters are recommended.

\section{References:}

1. Crossman AR. ed. Neuroanatomy. In: Standring $\mathrm{S}$, Ellis $\mathrm{H}$, Heally JC. et al. eds. Gray's Anatomy: The anatomical basis of clinical practice. $39^{\text {th }}$ ed. Edinburgh: Elsevier Churchill Livingstone; 2005. p. 380-3.

2. Krause wJ. Hypophysis. 2010. Available athttp://web.mac.com/wjkrause/iweb/histology/ htm. accessed on 2/2/2010.

3. Dietrich RB, LIs LE, Greensite FS, Pitt D. Normal MR Appearance of the Pituitary Gland in the First 2 Years of Life. AJNR. 1995; 16: 1413-9.

4. Hemminki K, Forsti $A$ and Ji j. Incidence and Familial risks in pituitary adenoma and associated tumors. Endocrine related cancer, 2007;14: 103-09.

5. Akhter N, Hassan S A.Subclinical hypothyroidism and hyperprolactinemia in infertile women: Bangladesh perspective after universal salt iodination. Int J endo, 2009;

6. Aron DC, Findling JW, Tyrrell JB. eds. Hypothalamus and pituitary gland. In: Greenspan FS, Gardner DG. eds. Basic and clinical endocrinology. $7^{\text {th }}$ ed. New York: McGraw Hill; 2004. p. 106-163.

7. Maitra A, Abbas KA. eds. Diseases of the endocrine system. In: Kumar V, Abbas AK, Fausto N. eds. Robbins and Cotran pathologic basis of disease. $7^{\text {th }}$ ed. New Delhi: Saunders; 2004. p. 1156-64. 
8. Asa SL. Pituitary Histopathology in Man : Normal and Abnormal. Endotext.com. 2007; Available at-c:Idocuments and setting/user/ desktop/p.t.g./ptg/histoathologyu.html.

9. Tsunoda A, Okuda O, Sato K. MR Height of the Pituitary Gland as a function of age and sex: Especially Physiological Hypertrophy in Adolescence and in Climactorium. AJNR,1997;18:551-4.

10. Cox TD, Elster AD. Normal Pituitary Gland: Changes in the shape, size and signal intensity during the $1^{\text {st }}$ year of life at MR Imaging. Radiology, 1991;179: 721-4.

11. McLachlan MSF, Williams ED, Fortt RW, Doyle FH. Estimation of pituitary gland dimensions from radiographs of the sella turcica: A post mortem study. Br. J. Radiol, 1968; 41: 323-30.

12. Fawcett DW. ed. Bloom and Fawcett - a textbook of histology. $12^{\text {th }}$ ed. New York: Chapman \& Hall; 1994. p. 473-88.

13. Gartner LP and Hiatt LJ. ed. Endocrine system. Colour textbook of histology: study of human structure. $2^{\text {nd }}$ ed. Philadelphia: W B Saunders Company; 2001. p. 302-9.

14. MescherAL. ed. Junqueira's basic histology. $12^{\text {th }}$ ed. Singapore: McGraw-Hill; 2010. p. 348-56.
15. Oon CK, Lavender JP, Joplin GF. The width of the normal pituitary gland: A comparison of two radiological methods of measurement. Departments of Radiodiagnosis and Medicine. 1961;35(414):418-21.

16. Kelly DE, Wood RL, Enders AC. eds. The endocrine glands. Bailey's textbook of microscopic anatomy. $18^{\text {th }}$ ed. Baltimore: Williams \& Wilkins; 1984. p. 778-94.

17. Argyropoulou M, Perignon F, Brunelle F, Brauner R, Rappaport R. Height of normal pituitary gland as a function of age evaluated by magnetic resonance imaging in children. Pediatr Radiol,1991;21: 247-9.

18. Tien RD, Kucharczyk J, Bessette J, Middleton M. MR Imaging of the pituitary gland in infants and children: Changes in size, shape and MR signal with growth and development. AJR, 1992;158: 1151-4.

19. Wolpert SM, Molitch ME, Goldman JA, Wood JB. Size, Shape and Appearance of the Normal Female Pituitary Gland. AJR, 1984;143: 37781.

20. Elster AD, Chen MYM, Williams III DW, Key L L. Pituitary gland: MR Imaging of Physiologic Hypertrophy in Adolescence. Radiology, 1990; 174: $681-5$. 